\title{
THE POTENTIAL OF GREEN INFRASTRUCTURE (GI) FOR REDUCING STORMWATER RUNOFF IN A PHNOM PENH NEIGHBORHOOD
}

\author{
Chanrachna NOU ${ }^{1}$, Sasima CHAROENKIT ${ }^{2}$ (i)
}

DOI: 10.21163/GT_2020.151.10

\begin{abstract}
:
Any increase in impervious ground surfaces due to urban growth tends to intensify stormwater management problems. Partial urban flooding can occur any time when the volume of stormwater exceeds local drainage capacity. Phnom Penh has suffered from urban flooding for more than a decade because of the limited capacity of the city's drainage system. Numerous studies have investigated and proposed the use of green infrastructure (GI) as a tool for mitigating flooding due to stormwater runoff. The purpose of this study is to investigate the potential of proposed GI features for reducing stormwater runoff in central Phnom Penh. By using the Rational method, the peak discharge was analyzed and estimated for Tuol Svay Prei Pir, a central Phnom Penh neighborhood that experiences frequent flood problems. The runoff peaks produced by the current practices (S1), and the proposed practices that integrate with the GI features (S2) were compared. The results show that an increase in pervious surface up to $48.14 \%$ by implementing the four GI features; trees, bioswales, permeable pavements, and green roofs, the runoff rate will be reduced by $37.90 \%$, which is equivalent to a reduction of $1.55 \mathrm{~m}^{3} / \mathrm{s}$ during peak runoff.
\end{abstract}

Key-words: Green Infrastructure (GI), Stormwater runoff, Rational method, Phnom Penh.

\section{INTRODUCTION}

Urban growth affects urban hydrology. Dramatic changes in land use in urbanized processes, from a natural landscape covered by vegetation to a built environment, leads to an increase in runoff volume due to larger areas of impermeable surfaces. Increases in urban development have become a major challenge in urban hydrology (Li et al., 2018). Extensive urban impermeable surfaces, particularly the construction of buildings, parking lots, roads, and sidewalks are the result of human activity (Malik et al., 2019). These activities disturb the urban hydrological cycle by reducing infiltration and increasing stormwater runoff. Higher amounts of runoff are likely to contribute to flood damage in urban areas.

Stormwater runoff has become one of the challenges for cities coping with floods. Once the rainfall intensity is greater than the water conductivity of impervious surfaces, urban floods occur because it is difficult for water to percolate into the subsoil. An excess runoff not only provokes urban flooding, but it also results in other environmental problems related to water pollution, local drought conditions and erosion in streams. Accordingly, many cities in the world are adapting themselves to become more resilient to flooding by applying concepts related to sustainable stormwater runoff reduction, such as green infrastructure (GI), low impact development (LID), best management practices (BMPs), sustainable urban drainage systems (SUDS), and water-sensitive urban design (WSUD) (Fletcher et al., 2014). All these concepts share similar principles based on vegetation-based

\footnotetext{
${ }^{1}$ Naresuan University, Faculty of Architecture, Phitsanulok, Thailand, chanrachnanou@gmail.com;

${ }^{2}$ Naresuan University, Faculty of Architecture, Phitsanulok, Thailand, sasimacharoenkit@gmail.com.
} 
systems to alter urban hydrologic behavior and mitigate the environmental impact of stormwater runoff.

The integration of green infrastructure (GI) is promoted to minimize the drainage burden of cities. A variety of GI features are used to alleviate the negative impacts of extreme precipitation include street trees, bioretention system/rain gardens, permeable pavements, bioswales, the constructing of wetland systems, rainwater harvesting/rain barrels, and green roofs. The capacity of these GI features in absorbing stormwater is determined from the amount of water captured through subsurface infiltration and evapotranspiration rate. In addition, the potential of GI features for the reduction of runoff varies across climate zones. The retention's performance of GI reduce runoff volume by $48 \%, 67 \%, 34 \%$ when green roofs are applied in London Ontario (humid continental), Calgary Alberta (semi-arid, continental), and Halifax Nova Scotia (humid, maritime), respectively (Sims et al., 2016).

Despite the high rainfall intensity, less than 10 percent of studies were undertaken (Parker \& Baro, 2019). Phnom Penh, Cambodia, annually suffers from stormwater runoff issues due to increasing population and urban development occurring on the low-lying areas. Covering an area of $678.47 \mathrm{Km}^{2}$ with inadequate stormwater management systems, this city is highly vulnerable to urban flooding. Flood characteristics in Phnom Penh caused by two patterns: Monsoon rains (flood level reaches $1.5 \mathrm{~m}$ in some parts during rainy season), and Mekong river floods (with the depth of $12 \mathrm{~m}$ between dry and rainy seasons and last for weeks) (Doyle, 2012). Therefore, to reduce flooding problems, GI can be the potential measure integrating with existing drainage systems. This study aims to investigate the potential of GI features for stormwater runoff reduction in central urban area of Phnom Penh.

\section{PERFORMANCES OF GI FEATURES FOR REDUCING STORMWATER RUNOFF}

In this study, four GI features including trees, bioswales, permeable pavements and green roofs were selected to be implemented since they are common features of GI networks in several cities worldwide. Trees are basically composed of tree canopies, stems, and tree pits. These components intercept, infiltrate, and evaporate to reduce stormwater runoff and decrease rainfall intensity. Coniferous trees intercept $30 \%$ of rainfall more than deciduous trees because of tree properties (leaves, bark, and branches) (Zabret \& Šraj, 2015 ) and the tree canopies can evaporate form $6.5 \%$ to $27 \%$ of the total rainfall (Kirnbauer et al., 2013). In urban areas, trees and pits could reduce runoff from asphalt with the maximum of $62 \%$ (Armson et al., 2013).

Bioswales are vegetated drainage channels designed with underlying engineered soil structures to capture and treat stormwater runoff. Three components of bioswales include vegetation, substrate, and soil. The ability to reduce stormwater runoff of bioswales integrating with engineered soil and trees is up to $88.8 \%$ from parking lot in a Mediterranean climate (Xiao \& McPherson, 2011), while approximately 48 - 96\% of storm events were captured in humid continental climate (Shrestha et al., 2018).

Permeable pavements are typically pervious concretes (PCs) and porous asphalts (PAs). Other types of permeable pavements are block pavers with mixed design material like concrete and plastic; either side joint with fine sand or grasses planted in open surface (e.g. permeable interlocking concrete pavers (PICPs), concrete grid pavers (CGPs), and plastic reinforcement grid pavers (PRGPs). 
They reduce runoff through three mechanisms: storage in the subbase, an evaporation of pavement basecourse, and an exfiltration into subgrade soils. The percentage of runoff reduction of porous pavements varied between $45 \%$ to $55 \%$ for peak discharge and $50 \%$ to $60 \%$ for runoff volume reduction (Jayasuriya \& Kadurupokune, 2010).

Green roofs, due to the depth of substrate, commonly divided into two types: extensive green roofs and intensive green roofs. The extensive green roofs basically have a substrate depth less than $150 \mathrm{~mm}$ and more than $150 \mathrm{~mm}$ of substrate depth for the intensive green roofs which allow a variety of vegetations to be planted (Uhl \& Schiedt, 2008). The typical layers in green roofs; vegetation, substrate, filter fabric, and drainage plate, reduce rainwater through retaining and evaporating. The capacities of rainfall reduced by evapotranspiration for these green roofs were from $49.9 \%$ to $57.2 \%$ in tropical climates (Viola et al., 2017).

\section{METHODOLOGY}

\subsection{Study area}

A neighborhood in the center of Phnom Penh, Tuol Svay Prei Pir (TSPP) $\left(11^{\circ} 33^{\prime} 11.84^{\prime \prime} \mathrm{N}, 104^{\circ} 54^{\prime} 21.21^{\prime \prime} \mathrm{E}\right)$ has a total area of 35.80 ha, was selected as our case study, because it has experienced severe flooding for more than a decade, and represents a typical residential area characterized by linked housing and streets as shown in Fig. 1. Due to the large impervious surfaces, which accounts to approximately $90-95 \%$ of the total area, TSPP is usually flooded during heavy rain. The estimated flood depth commonly ranges from $0-1 \mathrm{~m}$ (Hong et al., 2016) and lasts between $1.5-3.0$ hours. The average annual temperature is $28{ }^{\circ} \mathrm{C}$, ranging from $17{ }^{\circ} \mathrm{C}$ to $38{ }^{\circ} \mathrm{C}$, and the average rainfall of 1400 $\mathrm{mm}$ annually, and is governed by a monsoon tropical climate, characterized by two major seasons; rainy (May - Oct) and dry (Nov - April) (Thoeun et al., 2014).

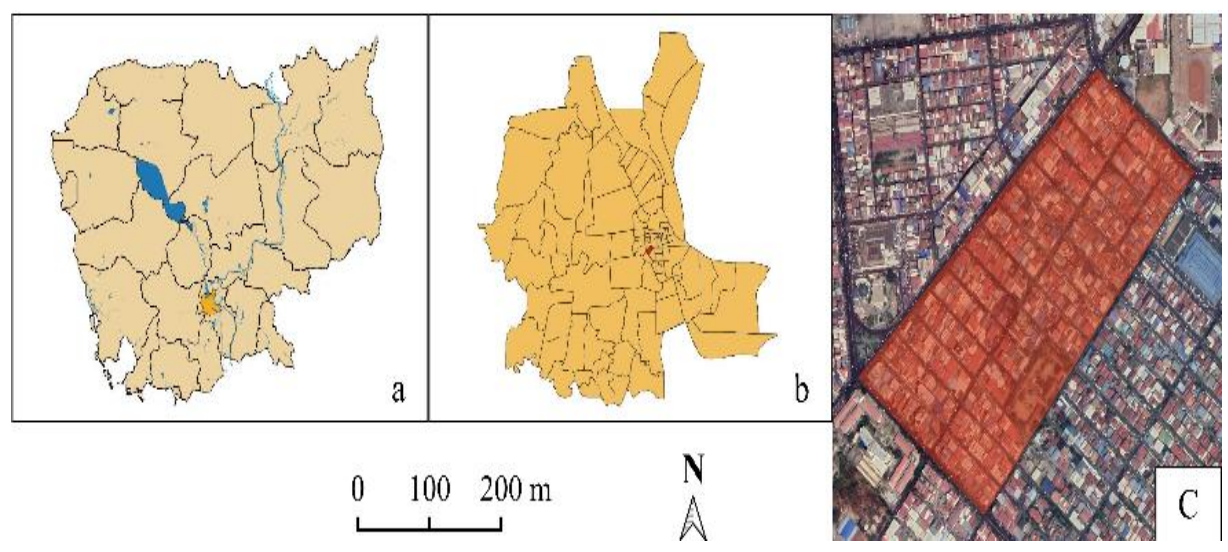

Fig. 1. Cambodia (a), Phnom Penh (b), and study area: Tuol Svay Prei Pir (c) (Source: Open Development Cambodia, ODC) 


\subsection{Overall framework}

The investigation of GI's performance in this study was conducted by comparing runoff peaks between two scenarios. Scenario 1 (S1) referred to the existing practices without GI implementation, named as non-GI. Scenario 2 (S2) referred to the proposed practices in which GI features are integrated as illustrated in Fig. 2.

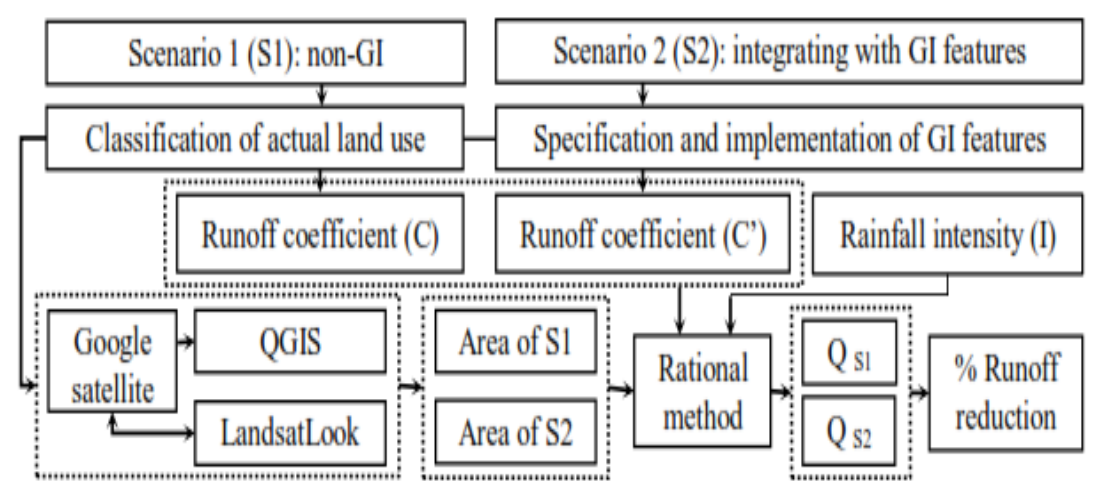

Fig. 2. Overall framework for quantifying the percentages reduction of stormwater runoff.

We want to note that the idea of scenarios is not new in hydrology. Haidu et al. (2017) developed a GIS module in order to elaborate stormwater runoff scenarios for different hypothetical storms.

\subsection{Scenario 1 (non-GI)}

\subsubsection{Land use/cover classification}

Land use/cover classification of the study area was obtained by using QGIS version 3.4 with an overlay of Google satellite, which was confirmed by LandsatLook, made by USGS (2019) for achieving clearer views.

The impervious and pervious surfaces of the study area were further identified by using Google earth pro to determine the land cover types. Houses/buildings, paths, parking lots, campuses, sidewalks, roads, boulevards, and bare land were classified as impervious surfaces, while pervious surfaces were referred to those areas covered by tree canopies and grasses.

\subsubsection{Runoff coefficient $(C)$}

There are many manuals, articles and references for equivalent runoff coefficient formulas, that can be used in the rational method (Costea, 2013; Györi et al., 2016; Haidu \& Ivan, 2016; Voda et al., 2018).

In scenario 1, the selection of $\mathrm{C}$ values for each part of land covered is based on the Hydraulic Design Manual of Texas Department of Transport (Garcia, 2016). Some of the C values of the land covers that appear in scenario 1 are identical to the ones mentioned in the design manual. Therefore, $\mathrm{C}$ of similar land covers were selected and determined by their mean values, as shown in Table 1. 
Table 1.

Runoff coefficient $(C)$ of actual land covers

(source: Garcia, 2016: chapter 4: Hydrology, section 12-Rational method, p. 4-53 \& 4-54).

\begin{tabular}{|c|c|c|c|}
\hline \multirow{2}{*}{\multicolumn{2}{|c|}{ Land use/cover }} & \multirow{2}{*}{\multicolumn{2}{|c|}{ Runoff coefficient $(\mathrm{C})$}} \\
\hline & & & \\
\hline \multirow[t]{3}{*}{$\begin{array}{l}\text { Trees: tree } \\
\text { canopies }\end{array}$} & $\begin{array}{l}\text { Over impervious } \\
\text { concrete }\end{array}$ & $\begin{array}{l}C_{\text {unimproved area (steep grassed slopes) }}=0.70 \\
\mathrm{C}_{\text {streets (concrete) }}=0.90-0.95\end{array}$ & 0.8125 \\
\hline & $\begin{array}{l}\text { Over impermeable } \\
\text { pavers }\end{array}$ & $\begin{array}{l}\mathrm{C}_{\text {unimproved area (steep grassed slopes) }}=0.70 \\
\mathrm{C}_{\text {streets (drives and walks) }}=0.75-0.95\end{array}$ & 0.775 \\
\hline & $\begin{array}{l}\text { Over impervious } \\
\text { asphalt }\end{array}$ & $\begin{array}{l}\mathrm{C}_{\text {unimproved area (steep grassed slopes) }}=0.70 \\
\mathrm{C}_{\text {streets (asphalt) }}=0.85-0.95\end{array}$ & 0.80 \\
\hline Parks & Grass & $\mathrm{C}_{\text {lawn (sandy soil, flat } 2 \%)}=0.05-0.10$ & 0.075 \\
\hline \multirow[t]{2}{*}{ Houses/buildings } & Sloped roofs & \multirow[t]{2}{*}{$\mathrm{C}_{\text {roofs }}=0.75-0.95$} & 0.95 \\
\hline & Flat roofs & & 0.75 \\
\hline $\begin{array}{l}\text { Paths/campuses/ } \\
\text { parking lots/bare } \\
\text { lands }\end{array}$ & Impervious concrete & $\mathrm{C}_{\text {streets } \text { (concrete) }=0.90-0.95}$ & 0.925 \\
\hline Sidewalks & Impermeable pavers & $\mathrm{C}_{\text {streets (drives and walks) }}=0.75-0.95$ & 0.85 \\
\hline Roads/boulevards & Impervious asphalt & $\mathrm{C}_{\text {streets (asphalt) }}=0.85-0.95$ & 0.90 \\
\hline
\end{tabular}

\subsection{Scenario 2 (integrating with GI features)}

\subsubsection{Specification of GI features}

Trees are mainly grown on/near sidewalks, parking lots (alone or in bioswales), and roadways. In this study, sidewalks are divided into two types: one-side along boulevards with $4-6 \mathrm{~m}$ wide and two-side along roads, which are $2 \mathrm{~m}, 2.5 \mathrm{~m}, 4 \mathrm{~m}, 6 \mathrm{~m}$ wide (measured by calculating the existing tiles through Google Earth Pro, street view). Therefore, the sizes of pits were $4 \mathrm{~m}^{2}$ for one-side along boulevards and $1 \mathrm{~m}^{2}$ for two-side along roads and were placed $8 \mathrm{~m}$ from each on sidewalks. The average radius of street trees canopies ranges from $1.8-5.2 \mathrm{~m}$ (Pretzsch et al., 2015). Hence, $1.8 \mathrm{~m}$ and $3 \mathrm{~m}$ of tree canopies radius are applied on one-side along the boulevards and two-sides along roads in term of sidewalks' width. In these values, the tree canopies may cover sidewalks, roads, and boulevards. We assumed that tree canopies cover over roads and boulevards with onethird and two-thirds of total tree canopies, respectively.

Bioswales are suitable for implementing alongside streets/roadsides, residential roadways and on parking lots. In this study, the width of boulevards measured in QGIS, with an overlay of Google satellite, were between $18-20 \mathrm{~m}$ for four lanes, and the four boundaries were in the middle of boulevards and roads (Fig. 1 (c)). Thus, the bioswales with a half width of $2.4 \mathrm{~m}$ can be replaced an existing concrete median barrier on boulevards since the width of each traffic lane on residential streets must be at least $3.35 \mathrm{~m}$ (MacAdam, 2012). The other land use such as paths, campus, and parking lots are not applicable for bioswales because they were too narrow. Table 2 summarizes GI features applied for the study area.

Permeable pavements are commonly installed in pedestrian areas/sidewalks, low volume roads, and parking areas. Here, the replacement of permeable pavements was based on the existing surfaces. For example, impervious concrete/asphalt and impermeable pavers were replaced by pervious concrete/porous asphalt and permeable pavers, respectively. 
Specification of GI features on actual land use/cover, (*) no GI features.

Table 2.

\begin{tabular}{|c|c|c|c|}
\hline \multicolumn{2}{|l|}{ S1 } & \multicolumn{2}{|l|}{ S2 } \\
\hline Land use & Land covers & GI features & Specification \\
\hline \multirow[t]{2}{*}{ Houses/buildings } & Sloped roofs & $*$ & * \\
\hline & Flat roofs & Green roofs & Fully covered \\
\hline \multirow{3}{*}{$\begin{array}{l}\text { Two sides of } \\
\text { sidewalks along } \\
\text { roads }\end{array}$} & $\begin{array}{l}\text { Tree canopies over } \\
\text { impermeable pavers }\end{array}$ & $\begin{array}{l}\text { Tree canopies over } \\
\text { permeable pavers }\end{array}$ & $\begin{array}{l}\text { Tree canopies radius }=1.8 \mathrm{~m} \\
\text { Two-third of tree canopies }\end{array}$ \\
\hline & No pits & Pits & $1 \mathrm{~m}^{2}$, placed $8 \mathrm{~m}$ each \\
\hline & Impermeable pavers & Permeable pavers & $\begin{array}{l}\text { Area without pits and tree } \\
\text { canopies area }\end{array}$ \\
\hline \multirow{3}{*}{$\begin{array}{l}\text { One side of } \\
\text { sidewalks along } \\
\text { boulevards }\end{array}$} & $\begin{array}{l}\text { Tree canopies over } \\
\text { impermeable pavers }\end{array}$ & $\begin{array}{l}\text { Tree canopies over } \\
\text { permeable pavers }\end{array}$ & $\begin{array}{l}\text { Tree canopies radius }=3 \mathrm{~m} \\
\text { Two-thirds of tree canopies }\end{array}$ \\
\hline & No pits & Pits & $4 \mathrm{~m}^{2}$, placed $8 \mathrm{~m}$ each \\
\hline & Impermeable pavers & Permeable pavers & $\begin{array}{l}\text { Area without pits and tree } \\
\text { canopies area }\end{array}$ \\
\hline \multirow[t]{3}{*}{ Boulevards } & Impervious asphalt & Porous asphalt & $\begin{array}{l}\text { Area without bioswale and } \\
\text { tree canopies area }\end{array}$ \\
\hline & & Bioswales & $1.2 \mathrm{~m}$ wide \\
\hline & $\begin{array}{l}\text { Tree canopies over } \\
\text { impervious asphalt }\end{array}$ & $\begin{array}{l}\text { Tree canopies over } \\
\text { boulevards }\end{array}$ & $\begin{array}{l}\begin{array}{l}\text { One-third of total tree } \\
\text { canopies }\end{array} \\
\end{array}$ \\
\hline \multirow[t]{2}{*}{ Roads } & Impervious asphalt & Porous asphalt & Area without tree canopies \\
\hline & $\begin{array}{l}\text { Tree canopies over } \\
\text { impervious asphalt }\end{array}$ & $\begin{array}{l}\text { Tree canopies over } \\
\text { porous asphalt }\end{array}$ & One-third of tree canopies \\
\hline Parks & Grass & $*$ & $*$ \\
\hline \multirow{2}{*}{$\begin{array}{l}\text { Paths, campus, } \\
\text { parking lots, and } \\
\text { bare land }\end{array}$} & Tree canopies & $*$ & $*$ \\
\hline & Impervious concrete & Pervious concrete & Fully covered \\
\hline
\end{tabular}

To facilitate water flow, the slope of the extensive green roof should be limited up to $45^{0}$ and $10^{\circ}$ for intensive green roofs (Mentens et al., 2006). Particularly, green roofs are applied on only flat roofs due to a difficulty to identify the degree of sloped roofs in this study. Some land uses/covers remain the same according to the specification designs of GI features.

\subsubsection{Runoff coefficient (C') of GI features}

Runoff coefficient (C') of GI features were acquired from other literatures and determined by mean values of each features as illustrated in Table 3 .

\subsection{Rational method}

Rational method was originally proposed by Mulvany (1850). It is used to calculate peak rate runoff in urban or suburban watershed and it is suitable for calculating runoff peak in urban and suburban area with drainage areas less than 80 ha.

$$
Q=\frac{1}{360} C I A \quad(\text { S.I unit })
$$


where,

$\mathrm{Q}=$ maximum rate of runoff $\left(\mathrm{m}^{3} / \mathrm{sec}.\right) ; \quad \mathrm{I}=$ average rainfall intensity $(\mathrm{mm} / \mathrm{hr}$.);

$\mathrm{C}=$ runoff coefficient;

$\mathrm{A}=$ drainage area $(\mathrm{ha})$.

Then,

$$
\% \text { Runoff reduction }=\frac{Q_{S 1}-Q_{S 2}}{Q_{S 1}}
$$

The average rainfall intensity (I) is constant while runoff coefficient (C) and drainage area (A) are variables. Due to a lack of data of design rainfall intensity (I), this study used (I) that acquired from Pochentong meteorological station in Phnom Penh (JICA, 2016). Hence, a 2-year storm return period, equals to $44.8 \mathrm{~mm} / \mathrm{h}$, was used to input in (1).

Table 3.

Runoff coefficient (C') of GI features.

\begin{tabular}{|c|c|c|c|}
\hline \multirow{2}{*}{\multicolumn{2}{|c|}{$\begin{array}{l}\text { Scenario 2 } \\
\text { GI features }\end{array}$}} & \multicolumn{2}{|l|}{ Runoff coefficient (C') } \\
\hline & & From other studies & This study \\
\hline \multirow{4}{*}{$\begin{array}{l}\text { Trees: tree } \\
\text { canopies }\end{array}$} & Over pits & $\mathrm{C}_{\text {trees }}=0.20-0.26$ (Armson et al., 2013) & 0.23 \\
\hline & $\begin{array}{l}\text { Over permeable } \\
\text { pavers }\end{array}$ & $\begin{array}{l}\mathrm{C}_{\text {trees }}=0.20-0.26 \text { (Armson et al., 2013) } \\
\mathrm{C}_{\text {Block pavers }}=0.20-0.50 \text { (Hunt et al., 2002) } \\
\mathrm{C}_{\text {Plastic grid pavers }}=0-0.26 \text { (Dreelin et al., 2006) }\end{array}$ & 0.47 \\
\hline & Over porous asphalt & $\begin{array}{l}\left.\mathrm{C}_{\text {trees }}=0.20-0.26 \text { (Armson et al., } 2013\right) \\
\mathrm{C}_{\text {porous asphalt }}=0.23(\mathrm{NYC}, 2012)\end{array}$ & 0.465 \\
\hline & $\begin{array}{l}\text { Over pervious } \\
\text { concrete }\end{array}$ & $\begin{array}{l}\mathrm{C}_{\text {trees }}=0.20-0.26 \text { (Armson et al., 2013) } \\
\mathrm{C}_{\text {pervious concrete }}=0.20 \text { (Dietz, 2007) }\end{array}$ & 0.45 \\
\hline Bioswales & & $\begin{array}{l}\mathrm{C} \text { bioswales }=0-0.06 \text { (Xiao \& McPherson, 2011) } \\
\text { and } 0.227 \text { (Sun et al., 2014) }\end{array}$ & 0.13 \\
\hline \multirow{3}{*}{$\begin{array}{l}\text { Permeable } \\
\text { pavements }\end{array}$} & Porous asphalt & $\mathrm{C}_{\text {porous asphalt }}=0.23(\mathrm{NYC}, 2012)$ & 0.23 \\
\hline & Pervious concrete & $\mathrm{C}_{\text {pervious concrete }}=0.20($ Dietz, 2007) & 0.2 \\
\hline & Permeable pavers & $\begin{array}{l}\mathrm{C}_{\text {block pavers }}=0.20-0.50 \text { (Hunt et al., 2002) } \\
\mathrm{C}_{\text {plastic grid pavers }}=0-0.26 \text { (Dreelin et al., 2006) }\end{array}$ & 0.24 \\
\hline $\begin{array}{l}\text { Green } \\
\text { roofs }\end{array}$ & & $\begin{array}{l}\mathrm{C} \text { green roofs }=0-0.44 \text { (Pimentel-Rodrigues \& } \\
\text { Silva-Afonso, 2017) and } 0.19-0.39 \text { (Uhl \& } \\
\text { Schiedt, 2008) }\end{array}$ & 0.255 \\
\hline
\end{tabular}

\section{RESULT AND DISCUSSION}

\subsection{Area and ratio of actual land use/cover}

With a total area of 35.80 ha, TSPP is divided into houses/buildings, transports, and the other areas are parks, paths, campuses, parking lots, and bare lands for $57.43 \%$ (20.56 ha), 33.83\% (12.11 ha), 8.74\% (3.13 ha), respectively, as shown in Fig. 3 (a).

\subsection{Implementation of GI features on actual land use}

Land covers on actual land use are changed after applying GI features as shown in Fig. 3 (b). Table 4 illustrates the area and ratio change between S1 and S2. The ratio of tree canopies is high, ranges from $163 \%-250 \%$, after trees are planted every $8 \mathrm{~m}$ on sidewalks. In total, 1,668 trees (and pits) are placed on sidewalks, 189 trees on one-side along 
boulevards and 1,479 trees on two-side along roads. Furthermore, the ratio changes of permeable pavements in S2 is lower than S1 because plenty of trees were implemented on sidewalks. Bioswales as well as green roofs are new features (100\% change), in this study area.

\begin{tabular}{|c|c|}
\hline $\begin{array}{l}\quad \text { Legend } \\
\text { Transports: } \\
\text { Tree canopies over sidewaiks } \quad \text { Flat roofs } \\
\text { Tree canopies over boulevards } \quad \text { Sloped roofs } \\
\text { Tree canopies over roads } \\
\text { Sidewalks: impermeable pavements } \\
\text { Boulcvards: impcrvious asphalt } \\
\text { Roads: impervious asphalt } \\
\text { Others: } \\
\text { Parks: grass } \\
\text { Tree canopies over paths, } \\
\text { cainpuses, and parking lots } \\
\text { Paths and campus: } \\
\text { impervious concrete } \\
\text { Palring lots: impervious } \\
\text { concrete } \\
\text { Barelands:impervious } \\
\text { concrete }\end{array}$ & 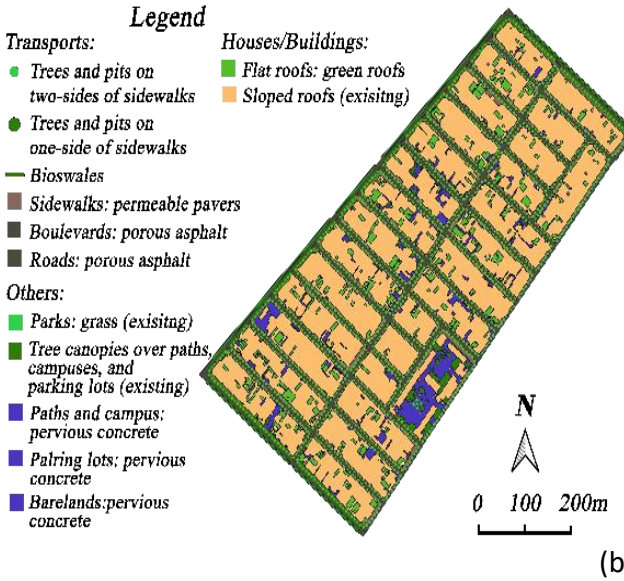 \\
\hline
\end{tabular}

Fig. 3. Land use/cover: scenario 1 (a), scenario 2 (b).

Table 4.

Area and ratio changes between S1 and S2, (*) no GI features.

\begin{tabular}{|c|c|c|c|c|c|}
\hline \multicolumn{3}{|c|}{ S 1} & \multicolumn{2}{|l|}{ S 2} & \multirow{2}{*}{$\begin{array}{c}\text { Changed } \\
(\%)\end{array}$} \\
\hline \multicolumn{2}{|l|}{ Land use/cover } & Area (ha) & Land cover & $\begin{array}{l}\text { Area } \\
\text { (ha) }\end{array}$ & \\
\hline \multirow[t]{2}{*}{ Houses/buildings } & Sloped roofs & 18.55 & $*$ & $*$ & 0 \\
\hline & Flat roofs & 2.01 & Green roofs & 2.01 & 100 \\
\hline Sidewalks & $\begin{array}{l}\text { Impermeable } \\
\text { pavers }\end{array}$ & 6.35 & Permeable pavers & 5.18 & 82 \\
\hline \multirow[t]{2}{*}{ Roads/boulevards } & Impervious asphalt & 5.75 & Porous asphalt & 5.31 & 92 \\
\hline & & & Bioswale & 0.18 & 100 \\
\hline Park & Grass & 0.01 & $*$ & $*$ & 0 \\
\hline \multirow[t]{4}{*}{ Trees } & $\begin{array}{l}\text { Tree canopies over } \\
\text { impervious } \\
\text { concrete }\end{array}$ & 0.46 & $\begin{array}{l}\text { Tree canopies } \\
\text { over pervious } \\
\text { concrete }\end{array}$ & 0.75 & 163 \\
\hline & $\begin{array}{l}\text { Tree canopies over } \\
\text { impermeable } \\
\text { pavers }\end{array}$ & 0.63 & $\begin{array}{l}\text { Tree canopies } \\
\text { over permeable } \\
\text { pavers }\end{array}$ & 1.58 & 250 \\
\hline & $\begin{array}{l}\text { Tree canopies over } \\
\text { impervious asphalt }\end{array}$ & 0.34 & $\begin{array}{l}\text { Tree canopies } \\
\text { over porous } \\
\text { asphalt }\end{array}$ & 0.60 & 176 \\
\hline & & & Tree pits & 0.22 & 100 \\
\hline The others & $\begin{array}{l}\text { Impervious } \\
\text { concrete }\end{array}$ & 1.69 & Pervious concrete & 1.40 & 83 \\
\hline
\end{tabular}


Tab. 5 shows the total area and ratio of each GI features in S2. It is obvious that permeable pavements have the highest ratio $(34.03 \%)$ comparing to the other features. The ratio of bioswales is minor $(0.51 \%)$ and this may be due to the limited space available in the area.

Table 5.

Area and ratio of GI features in $\mathbf{S} 2$.

\begin{tabular}{|c|c|c|c|c|}
\hline GI features & Trees (pits and canopies) & Bioswales & Permeable pavements & Green roofs \\
\hline Area (ha) & 2.86 & 0.18 & 12.18 & 2.01 \\
\hline Ratio (\%) & 8 & 0.51 & 34.03 & 5.61 \\
\hline
\end{tabular}

\subsection{Runoff reduction}

The results attained from a quantification of peak runoff using Rational method are shown in Table 6. Peak runoff in S1 in 2-year return period is $4.09 \mathrm{~m}^{3} / \mathrm{s}$. This value was similar to those computed by Heng et al. (2016) who quantified peak runoff rate of 1.42 $5.36 \mathrm{~m}^{3} / \mathrm{s}$ on a catchment next to ours (in the same district) (Heng et al., 2017). It can be observed that land use/cover type as well as urbanization reflecting a high-density residential area which tended to large runoff volumes. Meanwhile, a significant increase in pervious surface from $4.17 \%$ to $48.14 \%$, approximately decreased $1.55 \mathrm{~m}^{3} / \mathrm{s}$ of peak runoff and yielded a reduction of $37.90 \%$ of stormwater runoff peaks by using trees, bioswales, permeable pavements, and green roofs with a ratio of $8 \%, 0.51 \%, 34.03 \%$, and $5.61 \%$, respectively.

Table 6.

The runoff reduction after the implementation of GI features.

\begin{tabular}{|c|c|c|c|c|c|}
\hline \multicolumn{2}{|c|}{ Scenario } & \multirow{2}{*}{$\begin{array}{l}\text { Ratio (\%) } \\
4.17 \\
\end{array}$} & \multirow{2}{*}{$\begin{array}{l}\mathbf{Q}\left(\mathbf{m}^{\mathbf{3}} / \mathbf{s}\right) \\
0.27\end{array}$} & \multirow{2}{*}{ 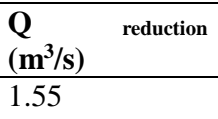 } & \multirow{2}{*}{$\begin{array}{l}\text { Runoff reduction (\%) } \\
37.90\end{array}$} \\
\hline S1 & Pervious & & & & \\
\hline & Impervious & 95.83 & 3.81 & & \\
\hline \multirow[t]{2}{*}{ S2 } & Pervious & 48.14 & 0.57 & & \\
\hline & Impervious & 51.86 & 1.96 & & \\
\hline
\end{tabular}

The percentage of stormwater runoff reduction reported here is larger than in previous studies. A study of US cities which have a diversity of climate zones, presents lower runoff reduction rates which varied between 18 - 29\% after implementing swales/infiltration (12\%), bioretention (23\%), and green roof (33\%) (Sarkar et al., 2018). This rate can be expected because of a mean reduction of 11 locations with different climates, rather than an individual location (as with this study).

\section{CONCLUSION}

The aim of this study is to investigate the potential of proposed GI features for reducing stormwater runoff in central Phnom Penh. By using Rational method, the runoff peaks were estimated for Tuol Svay Prei Pir (TSPP), a central Phnom Penh neighborhood. The runoff peaks produced by the current practice (S1), and the proposed practices that integrate with the GI features (S2) were compared. The total runoff reduction was $37.90 \%$, which is the equivalent to a reduction of $1.55 \mathrm{~m}^{3} / \mathrm{s}$ during peak excess, due to an increase in pervious surfaces up to $48.14 \%$ of total area. Permeable pavements are the most effective feature in this study as they account for one-third (34.03\%) of the total area, followed by green roofs $(5.61 \%)$, trees $(8 \%)$, and bioswales $(0.51 \%)$, which demonstrate that GI features 
are effective in the reduction of stormwater. These features can be applied to all existing developments and integrated into new ones for urban flood control and storm water management planning. Our future research will investigate the potential of using the GI features in commercial and service zones and mixed land areas for runoff reduction.

Land cover changes have significant influences on urban hydrology, especially discharge, and surface runoff. The value of runoff coefficients ( $C$ and $C$ ') used in this study were derived from other literatures. To achieve more accurate values, runoff coefficients derived from site surveys, such as the slope of the land and its uses, and the soil types need to be considered.

Climate regions alter the quantity of the total runoff reduction performed by GI features. For example, the capacity of rainwater reduced by green roofs was estimated according to the value of rainfall and potential evapotranspiration. What is obvious is annual rainfall is high in a tropical monsoon climate; the runoff volume would be high after heavy daily rainfall. Therefore, throughout evapotranspiration (potentially, high evaporation in rainy season), GI features may perform better when they are properly implemented in a tropical climate, subject to soil depth.

This study proposes GI assessment and implementation regarding stormwater runoff reduction, as well as enhancing esthetics and the ecosystem. The construction of GI as a retrofit can be difficult, but it is accomplishable, and will influences private and public participation willingness. Our suggestions on these matters, particularly in Phnom Penh are:

a. Green roofs would be more promotable in such residential areas if sloped roofs were modified (Rachmansyah et al., 2019). so that runoff could be reduced more than the recent results. On an individual level, citizens need to collaborate for GI spatial benefits.

b. Once sidewalks are reorganized to be pedestrian-friendly (recently used for illegal parking and commercial activities), there would be opportunities to install bioswales along both sides of sidewalks, according to national regulations.

\section{REFERENCES}

Armson, D., Stringer, P., \& Ennos, A. R. (2013). The effect of street trees and amenity grass on urban surface water runoff in Manchester, UK. Urban Forestry \& Urban Greening, 12(3), 282-286. doi:10.1016/j.ufug.2013.04.001

Costea, G. (2013). Deforestation process consequences upon surface runoff coefficients. Catchment level case study from the Apuseni mountains, Romania. Geographia Technica, 8(1), 28-33.

Dietz, M. E. (2007). Low Impact Development Practices: A Review of Current Research and Recommendations for Future Directions. Water, Air, and Soil Pollution, 186(1-4), 351-363. doi:10.1007/s11270-007-9484-z

Doyle, S. E. (2012). City of water: architecture, urbanism and the floods of Phnom Penh. Nakhara Journal of Environmental Design and Planning.

Dreelin, E. A., Fowler, L., \& Ronald Carroll, C. (2006). A test of porous pavement effectiveness on clay soils during natural storm events. Water Res, 40(4), 799-805. doi:https://doi.org/10.1016/j.watres.2005.12.002

Garcia, R. (2016). Hydraulic Design Manual.

Gyori, M.M., Haidu, I. \& Humbert, J. (2016). Deriving the floodplain in rural areas for high exceedance Probability Having Limited Data Source. Environmental Engineering and Management Journal, 15(8), 1879-1887. 
Haidu, I., \& Ivan, K. (2016). Évolution du ruissellement et du volume d'eau ruisselé en surface urbaine. Étude de cas: Bordeaux 1984-2014, France. La Houille Blanche, 5, 51-56.

Haidu, I., Batelaan, O., Crăciun, A.I., \& Domnița, M. (2017). GIS module for the estimation of the hillslope torrential peak flow. Environmental Engineering and Management Journal, 16(5), 1137-1144.

Heng, S., Hong, P., \& Ly, S. (2017). Assessment of an Urban Drainage System in Phnom Penh Using Storm Water Management Model. Paper presented at the THA 2017 International Conference on "Water Management and Climate Change Towards Asia's Water-Energy-Food Nexus", Bangkok, Thailand.

Hong, V., Ly, S., \& Heng, S. (2016). Application of MIKE FLOOD Model to simulate inundation map in Phnom Penh. Paper presented at the Proceedings of the Second Seminar Urban Water Resource Management (JSPS Core-to-Core Program), Tokyo, Japan.

Hunt, B., Stevens, S., \& Mayes, D. (2002). Permeable pavement use and research at two sites in Eastern North Carolina.

Jayasuriya, N., \& Kadurupokune, N. (2010). Comparative performance of permeable and porous pavements. Paper presented at the International Conference on Sustainable Built Environment (ICSBE-2010), Kandy, Sri Lanka.

JICA (2016). The study on drainage and sewerage improvement project in Phnom Penh metropolitan area (Vol. Final report).

Kirnbauer, M. C., Baetz, B. W., \& Kenney, W. A. (2013). Estimating the stormwater attenuation benefits derived from planting four monoculture species of deciduous trees on vacant and underutilized urban land parcels. Urban Forestry \& Urban Greening, 12(3), 401-407. doi:10.1016/j.ufug.2013.03.003

Li, C., Liu, M., Hu, Y., Shi, T., Qu, X., \& Walter, M. T. (2018). Effects of urbanization on direct runoff characteristics in urban functional zones. Sci Total Environ, 643, 301-311. doi:10.1016/j.scitotenv.2018.06.211

MacAdam, J. (2012). Green Infrastructure for Southwestern Neighborhoods. In J. D. Tory Syracuse, Karilyn Roach (Ed.): Watershed Management Group.

Malik, I. B. I., Suparta, W., \& Dewancker, B. J. (2019). A Study of Population Density in Developing Countries. Geographia Technica, 14(Special Issue), 201-212. doi:10.21163/GT_2019.

Mentens, J., Raes, D., \& Hermy, M. (2006). Green roofs as a tool for solving the rainwater runoff problem in the urbanized 21st century? Landscape and Urban Planning, 77(3), 217-226. doi:10.1016/j.landurbplan.2005.02.010

NYC, E. P. (2012). Green Infrastructure Pilot Monitoring Report. Retrieved from NYC Environmental Protection

Parker, J., \& Zingoni de Baro, M. E. (2019). Green Infrastructure in the Urban Environment: A Systematic Quantitative Review. Sustainability, 11(11), 3182. doi:10.3390/su11113182

Pimentel-Rodrigues, C., \& Silva-Afonso, A. (2017). Determination of Runoff Coefficients with a View to Integration of Green Roofs with Rainwater Harvesting Systems. International Journal of Environmental Science, 2, 366-372.

Pretzsch, H., Biber, P., Uhl, E., Dahlhausen, J., Rötzer, T., Caldentey, J., . . Pauleit, S. (2015). Crown size and growing space requirement of common tree species in urban centres, parks, and forests. Urban Forestry \& Urban Greening, 14(3), 466-479. doi:10.1016/j.ufug.2015.04.006

Rachmansyah, A., Halim, L. F., \& Soemarno. (2019). Sustainable Development Approach to Residential Planning in the Rapid Growth Urban Area: A Case Study in Singosari District, Malang Region, East Java Province. Geographia Technica, 14(Special), 3-12. doi:10.21163/GT_2019.

Sarkar, S., Butcher, J. B., Johnson, T. E., \& Clark, C. M. (2018). Simulated Sensitivity of Urban Green Infrastructure Practices to Climate Change. Earth Interact, 22(13), 1-37. doi:10.1175/EID-17-0015.1 
Shrestha, P., Hurley, S. E., \& Wemple, B. C. (2018). Effects of different soil media, vegetation, and hydrologic treatments on nutrient and sediment removal in roadside bioretention systems. Ecological Engineering, 112, 116-131. doi:10.1016/j.ecoleng.2017.12.004

Sims, A. W., Robinson, C. E., Smart, C. C., Voogt, J. A., Hay, G. J., Lundholm, J. T., O’Carroll, D. M. (2016). Retention performance of green roofs in three different climate regions. Journal of Hydrology, 542, 115-124. doi:10.1016/j.jhydrol.2016.08.055

Sun, Y.-w., Li, Q.-y., Liu, L., Xu, C.-d., \& Liu, Z.-p. (2014). Hydrological simulation approaches for BMPs and LID practices in highly urbanized area and development of hydrological performance indicator system. Water Science and Engineering, 7(2). doi:10.3882/j.issn.16742370.2014.02.003

Thoeun, H., Sivakumar, M., \& Dube, O. (2014). Observed and projected Changes in temperature and rainfall in Cambodia. Weather and Climate Extremes, 131. doi:10.1016/j.wace.2015.02.001

Uhl, M., \& Schiedt, L. (2008). Green roof storm water retention-monitoring results.

Viola, F., Hellies, M., \& Deidda, R. (2017). Retention performance of green roofs in representative climates worldwide. Journal of Hydrology, 553, 763-772. doi:10.1016/j.jhydrol.2017.08.033

Voda, A.I., Şarpe, C.A. \& Voda, M. (2018). Methods of maximum discharge computation in ungauged river basins. Review of procedures in Romania. Geographia Technica, 13(1), 130137.

Xiao, Q., \& McPherson, E. G. (2011). Performance of engineered soil and trees in a parking lot bioswale. Urban Water Journal, 8(4), 241-253. doi:10.1080/1573062X.2011.596213

Zabret, K., \& Šraj, M. (2015). Can Urban Trees Reduce the Impact of Climate Change on Storm Runoff? Urbani Izziv, 26, S165-S178. 